\title{
OCORRÊNCIA DE ANTÊNULAS HETEROMÓRFICAS NO CAMARÃO DE ÁGUA DOCE MACROBRACHIUM ACANTHURUS (DECAPODA, CARIDEA)
}

\author{
Izumi, K.S. ${ }^{1}$; Rodrigues, M.M. ${ }^{1,2, *}$; López Greco, L. ${ }^{3}$ \& Bertini, G. ${ }^{1{ }^{*}}$ \\ ${ }^{1}$ Universidade Estadual Paulista (UNESP), Campus de Registro, \\ Laboratório de Biologia e Cultivo de Crustáceos (LABCRUST). \\ ${ }^{2}$ Instituto Federal de Educação, Ciência e Tecnologia do Espírito Santo (IFES), Campus de Piúma, \\ Laboratório de carcinicultura. \\ ${ }^{3}$ Universidad de Buenos Aires, CONICET, Instituto de Biodiversidad y Biología Experimental y Aplicada (IBBEA), \\ Facultad de Ciencias Exactas y Naturales, Departamento de Biodiversidad y Biología Experimental. \\ Laboratorio de Biología de la Reproducción y el Crecimiento de Crustáceos Decápodos. \\ *Autor correspondente: gibertini@registro.unesp.br
}

Crustáceos são capazes de regenerar membros perdidos através do ciclo de muda, incluindo o olho. Porém, nem sempre esses membros são capazes de serem regenerados perfeitamente, surgindo uma anomalia conhecida como heteromorfose, a qual trata-se da regeneração de um apêndice em uma localização estranha, geralmente como uma resposta à lesão natural ou artificial. Esse trabalho relata a primeira ocorrência de antênula heteromórfica em Macrobrachium acanthurus que foi verificada durante a realização de um experimento para avaliar o sucesso reprodutivo dessa espécie, tendo como base a fertilidade das fêmeas após a realização da ablação unilateral do pedúnculo ocular. Os camarões foram coletados no Rio Ribeira de Iguape, sul do estado de São Paulo e levados para o laboratório. Quarenta e quatro fêmeas maduras tiveram um dos olhos cortado na base do pedúnculo com uma tesoura. O tempo de permanência dos animais no experimento foi até a obtenção das larvas da primeira ninhada. No entanto, 32 fêmeas foram mantidas em laboratório por mais um ciclo reprodutivo. Em todas essas fêmeas foi detectada a regeneração de um apêndice semelhante a antênula no lugar do pedúnculo ocular extirpado. Algumas das antênulas heteromórficas se assemelharam à antênula original de $M$. acanthurus, mas em nenhum dos animais observados o pedúnculo apresentou a divisão exata em três segmentos. Em relação aos flagelos heteromorfos, estes possuíram comprimentos variáveis, mas em nenhum exemplar os flagelos se aproximaram do flagelo normal. Outras formas de regeneração produziram antênulas com ambos flagelos em diferentes graus de desenvolvimento desde ausente, rudimentar ou longo. A forma mais aberrante de regeneração produziu uma estrutura globular, semelhante a um olho, da qual surgiram vários flagelos rudimentares. Com relação a funcionalidade do apêndice heteromorfo há estudos que demonstram conexões funcionais entre elementos sensoriais no heteromorfo e o sistema nervoso central. Já no caso das antênulas heteromorfas de $M$. acanthurus, são necessários mais estudos para afirmar se elas realmente desenvolvem sua função quimiorreceptora e olfativa.

Palavras-chave: heteromorfose, ablação unilateral, camarão canela, anomalia. 